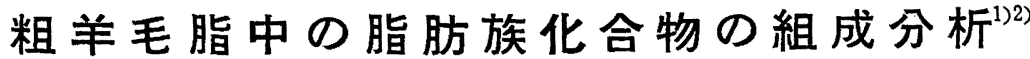

\author{
(1973 年 6 月 21 日 受理) \\ 高松翼・太田忠男・松 本勲*
}

\begin{abstract}
シリカゲルカラムクロマトグラフィーおよび MR 型アニオン交換樹脂（Amberlyst-A-27）を用い る非水系イオン交換クロマトグラフィーによるワックス成分の系統的分離法 ${ }^{2}$ に, 尿素カラムクロマト グラフィーを加え, 羊毛脂の成分を炭化水素, 遊離酸, 中性エステル（遊離アルコールを含む）に大別 し, さらにこれらを構成する脂肪酸, ヒドロキシ酸, 脂肪族アルコール, ステロールに分離し, これら のうち脂肪族化合物について，IR，TLC，GC 特よび一部については GC-MS により同定，確認を行 ない，各成分のるつ炭素数分布を求めた。その結果，各成分中の直鎖拉よびイソー, アンテイソーと呼 ばれる一連の分枝化合物は扔のおの特徵的な炭素数分布を有することがわかった。
\end{abstract}

\section{1 緒言}

羊毛脂中には，他の油脂，ロウ類にはほとんどみられない、イ ソー, アンテイソーと呼ばれるメチル分枝を有する脂肪酸了), 七ド

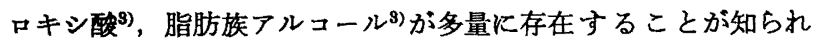
ており, 多くの研究者らによって, その存在, 構造が確認されて いる。しかしながら，いずれの場合にも各成分のるつ炭素数分布 など定量的な情報には乏しい。一方, Pelick ら よび GC-MS により羊毛脂中の分枝脂肪酸の構造を確認している が，この場合にるやはり定量的な検討はなされていない。これら 分枝化合物のるつ特殊な性質は化栍品工業においても非常に有用 であり，他の天然ワックス（カルナパ, ビース，キャンデリラワ ックス）ととるに，羊毛脂は必要欠くべからさる原料の一つとな っている。著者らは化料品に用いられるいろいろの天然ワックス の特性を，単に物理，化学定数のみでなく，その成分組成，各成 分のすつ炭素数分布を調べ化学的な面から解明しさら飞有効な利 用を進めることを目的として本研究を進めてきた。第 $1^{5)} ， 2^{2)}$ 報 では天然ワックス（カルナバ，ビース，キャンデリラワックス） の分析を通じて, 気相水素還元による高級脂肪酸, 高級アルコ一 ルの炭素数決定法, シリカゲルカラムクロマトグラフィーおよび MR 型アニオン交换樹脂 (Amberlyst A-27) を用いる非水系イ オン交換クロマトグラフィーによるワックス成分の系統的分離法 を設定し，その分析結果を報告した。本報ではこれらに引きつつ き粗羊毛脂をとりあげ，ワックス成分の系統的分離法に新たに尿 素カラムクロマトグラフィーを加え, 羊毛脂の成分を炭化水素, 遊離酸, 中性エステルK大別し，さらにこれらを構成する脂肪

1）この報文を“ワックス成分に関する研究(第3 報)”とする.

2）前報 (第 2 報), 松本 勲, 太田忠男, 高松 翼, 中野幹清, 日化，1972，951.

* 資生堂研究所 分析化学研究室, 115 東京都北区神谷町

3) E. V. Truter, "Wool Wax Chemistry and Technology", Cleaver-Hume Press Ltd. (1956).

4) N. Pelick, J. W. Shinaley, J. Amer. Oil Chem. Soc., 44, 121(1967).

5）松本 勲, 高松 翼, 太田忠男, 日化, 1972, 635 .
酸, ヒドロキシ酸，脂肪族アルコールを分離し，前二者について はメチルェステルとし SE-52 を固定相とする昇温 GCにより， 後者についてはトリメチルシリル化後, Dexsil 300 を固定相と するキャピラリーカラムを用いる昇温 GCKより, 各成分中の直 鎖, 括よびイソー, アンテイソー成分の炭素数分布を求めた結果, 招の括の特徵的な炭素数分布を有することがわかった。

\section{2 実験}

\section{1 試 料}

試料は原毛を洗浄するさいに得られる粗羊毛脂で日本クローダ 株式会社から提供を受けた。実験にさいしてはゴミ, 泥などの共 雑物をベンゼンを溶媒とする Soxhlet 抽出法で除去したものを 用いた。

\section{2 試薬および器具茈置}

（1）標準分枝脂肪酸メチルエステル混合試料: $\mathrm{C}_{14} \sim \mathrm{C}_{31}$ イ ソ-, アンテイソ-混合物 (Applied Science Laboratories)。

（2）標準直鎖， $\alpha$-ヒドロキシ酸メチルェステル混合試料: $\mathrm{C}_{14} \sim \mathrm{C}_{18}$ 混合物 (Applied Science Laboratories)。

（3）トリメチルシリル化削：TMS-HT（東京化成工業株式会 社)。

（4）水素化アルミニウムリチウム：試薬特級（和光純薬株式 会社)。

（5）無水エーテル：エチルエーテル試薬特級（和光純薬株式 会社）に金属ナトリウムを加え，脱水後，蒸留した。

（6）ガスクロマトグラフ用担体：セライト 545，60 80 メ ッシュ（日本クロマト工業株式会社）, 酸処理, ジメチルクロロ シラン処理, クロモソルブ G, 60〜80 メッシュ（日本クロマト 工業株式会社)。

（7）キャピラリーカラム: Dexsil 300, 内径 $0.5 \mathrm{~mm}$, 長さ $45 \mathrm{~m}$ ，ステンレス製（日立製作所）。

（8）ロータリエバポレーター：N-1 型(東京理化機械)。

（9）ガスクロマトグラフ：GC-4 A PTF 型(島津製作所), GC-063 型（日立製作所）。

(10) ディジタルインテグレーター：TR-2283 型（タケダ理 
研)

（11）その他の試楽拉よび器具，装置：前報2) に準ずる。

\section{3 実験方法}

四 1 亿成分分離フローシートを示した。前報と重複する部分に ついて，その操作法の詳細は省略した。

2.3.1 脂肪族アルコールとステロール類の分離 : シリカゲル カラムクロマトグラフィーにより，炭化水素と分離したアルュー ル部約 $0.5 \mathrm{~g}$ ，尿装 $4 \mathrm{~g}$ をベンゼン：メタノール $(1: 2 \mathrm{v} / \mathrm{v})$ 混 夜 $70 \mathrm{ml}$ に溶解し，七ライト $54515 \mathrm{~g}$ を加え， $30^{\circ} \mathrm{C}$ でロータ リーエバポレーターを用いて溶媒を留去した。内容物をスパーテ ルで十分に粉研後，クロマトグラフ管に充テンし，イソーオクタ ソ $200 \mathrm{ml}$ を流すと尿素と付加物を形成しないステロール類が溶 出しだ。ついで, ベンゼン:メタノール $(1: 2 \mathrm{v} / \mathrm{v})$ 混液 $300 \mathrm{ml}$ を流し, 溶出液は水浴上で溶媒を留去後, 蒸留水 $200 \mathrm{~m} l$, メ夕 ノール $50 \mathrm{ml}$, ベンゼン $50 \mathrm{ml}$ を加え, 分液漏斗に移し, 尿素付 加物を形成していた脂肪族アルコールを抽出した。水層を分離 後, ベンゼン $50 \mathrm{~m} l$ を加兄再度抽出を行ない，抽出液を合わせ， 十分に水洗した。

2.3.2 脂肪酸およびヒドロキシ酸の炭素数分布の分析 : 脂肪

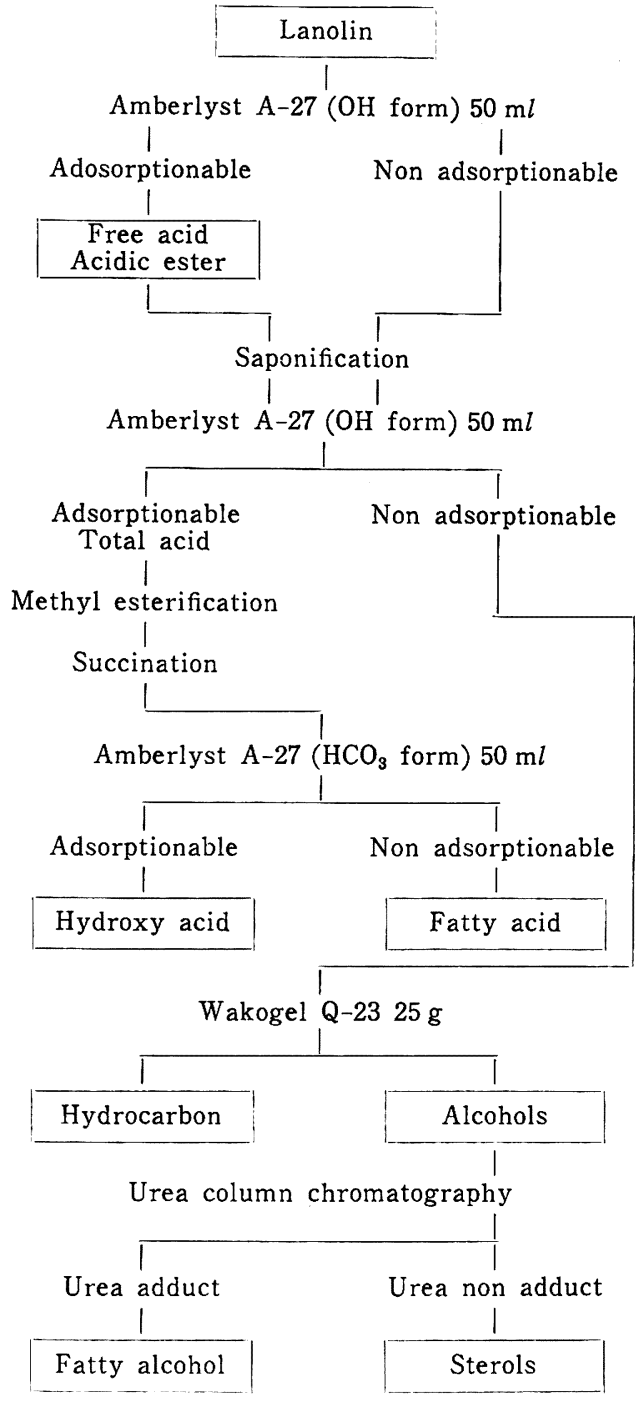

Fig. 1 Flow chart of analysis
Table 1 Gas chromatographic condition of fatty acid and hydroxy acid

Column : 10\% SE-52/Chromosorb G AW DMCS 60/80 $2 \mathrm{~m} \times 3 \mathrm{~mm} \phi$, Stainless steel

Column temp. : $160 \sim 320^{\circ} \mathrm{C}, 2^{\circ} \mathrm{C} / \mathrm{min}$

Detector : FID, $330^{\circ} \mathrm{C}$

Carrier gas : $\mathrm{He}, 60 \mathrm{ml} / \mathrm{min}$

Table 2 Gas chromatographic condition of fatty alcohol

Column : Dexsil 300 open tubular column $45 \mathrm{~m} \times 0.5 \mathrm{~mm} \phi$

Column temp. : $150 \sim 300^{\circ} \mathrm{C}, 2^{\circ} \mathrm{C} / \mathrm{min}$

Detector : FID, $330^{\circ} \mathrm{C}$

Carrier gas : $\mathrm{He}, 20 \mathrm{ml} / \mathrm{min}$

酸はメチルエステルとして分離されるのでそのまま，ヒドロキシ 酸はメチルェステルスクシナートとして得られるので, 加水分解 後再度メチルェステルとして表 1 に示した GC 条件のもとで分析 を行なった。各炭素数の組成はピーク面積百分率から求め, 保持 時間およびピーク面積の測定にはディジタルインテグレーターを 用いて行なった。

2.3.3 脂肪族アルコールの炭素数分布の分析 : 2.3.1 で分離 された脂肪族アルコール約 $10 \mathrm{mg}$ を共せん付 $10 \mathrm{ml}$ 三角フラス コにとり,トリメチルシリル化剤 TMS-HT 約 $1 \mathrm{~m} l$ を加え, 水 浴上で 10 分間加温し，表 2 に示した GC 条件のるとで分析を行 なった。

2.3.4 脂肪酸メチルエステルからアルコール，およびヒドロ キシ酸メチルエステルからジオールへの摆元 : 2.3 .2 で調製した 脂肪酸メチルエステル，またはヒドロキシ酸メチルエステル約 $100 \mathrm{mg}$ を $25 \mathrm{ml}$ 丸底フラスコにとり，水素化アルミニウムリチ ウム約 $250 \mathrm{mg}$, 無水エーテル $10 \mathrm{ml}$ を加え $50^{\circ} \mathrm{C}$ で 6 時間, 還 流後, 含水エーテル $10 \mathrm{ml}$, 蒸留水 $20 \mathrm{ml}, 6 \mathrm{~N}$ 塩酸 $50 \mathrm{ml}$ を 加分分液漏斗に移し, ベンゼン $30 \mathrm{~m} l$ で, 生成するアルコールま たはジオールを 2 回抽出した。

\section{3 実 験 結 果}

表 3 に粗羊毛脂の分析結果を示した。定量値は重量法により求 め, $n=2$ のくり返し実験の平均値である。

\section{1 遊 離 酸}

単離された遊離酸は茶褐色を呈し，その性状は樹脂状に近く， 一方, 遊離酸を除いた中性部は淡黄色のペースト状のすのが得ら れた。遊離酸部の $1700 \mathrm{~cm}^{-1}$ 付近の IR スペクトルおよび酸価, エステル価を図 2 に示したが，エステル結合をるつ酸, すなわち

Table 3 Analytical results of raw lanolin (\%)

$\begin{array}{cr}\text { Free acid } & 7.7 \\ \text { Fatty acid } & 2.8 \\ \text { Hydroxy acid } & 2.5 \\ \text { Alcohols } & 0.8 \\ \text { Unidentified } & 1.6 \\ \text { Neutral ester } & 91.9 \\ \text { Fatty acid } & 27.4 \\ \text { Hydroxy acid } & 21.7 \\ \text { Fatty alcohol } & 11.9 \\ \text { Sterols } & 30.9 \\ \text { Hydrocarbon } & 0.4\end{array}$




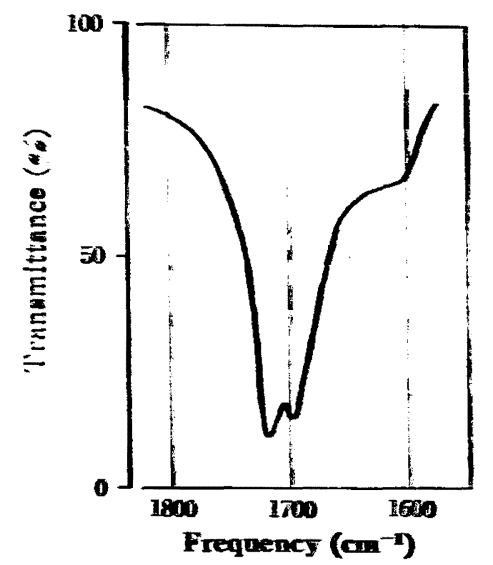

Fig 2 Infrared spectrum of free acid AV $: 482, E V: 749$

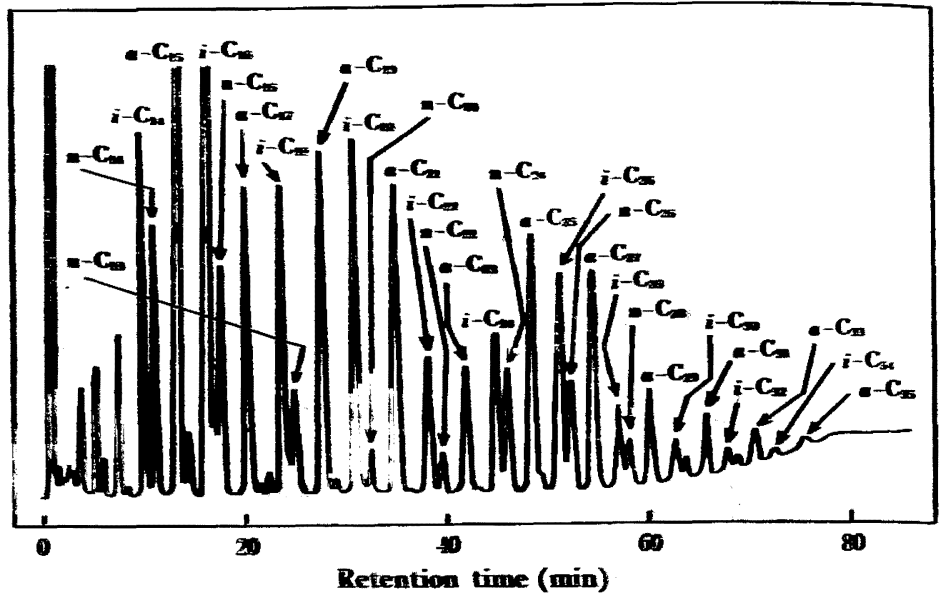

Fig. 3 Gas chromatogram of fatty acid methyl ester --: nornd, i- : ise, c- : anieiso-

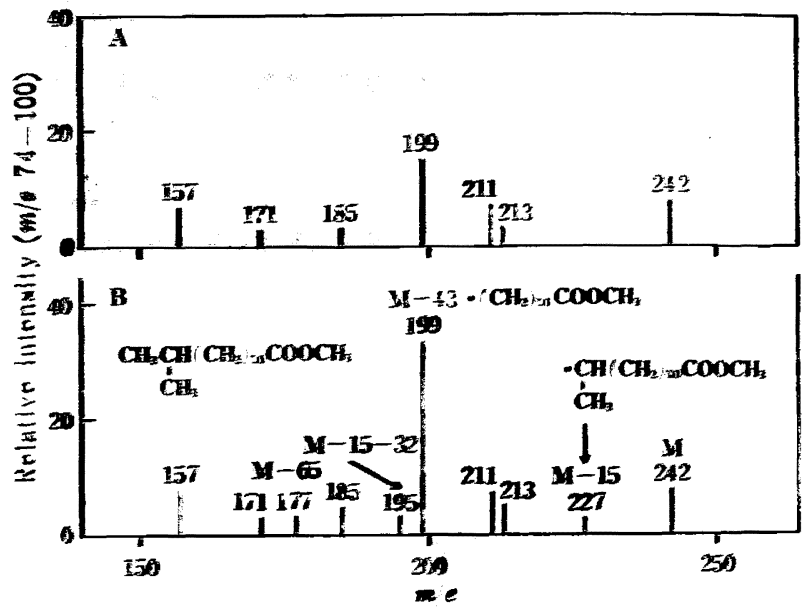

Fig 4 Mass spectram of - and $i c-C_{n}$ acid methyl ester

$$
A:=C_{14} \quad B=i s 0-C_{18}
$$

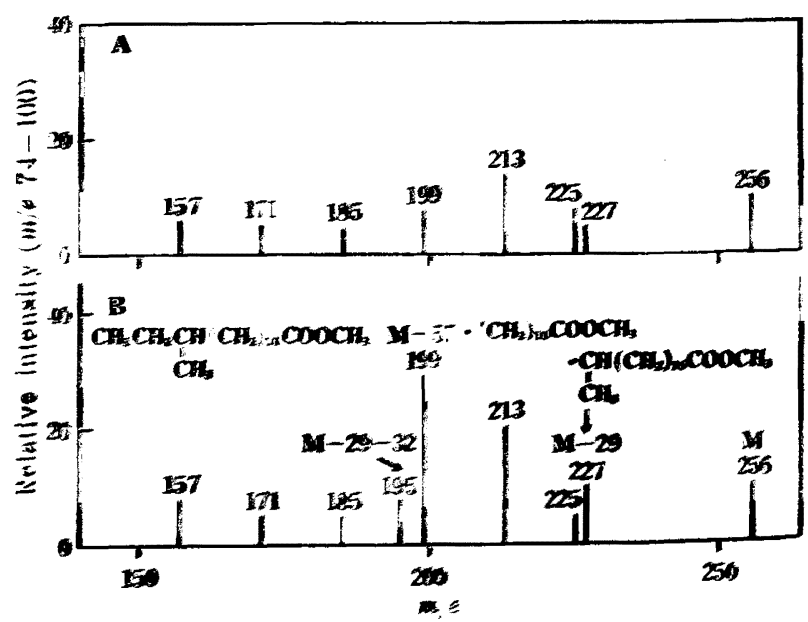

Fig 5 Mass spectrom of $*$ - and anteiso $C_{13}$ acid methyl ester

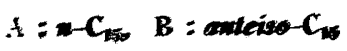

7 G. Odbam, Ark Kewi, 2 417(1964).

8) G. Odhar, itid, 23, 31 (195i). 


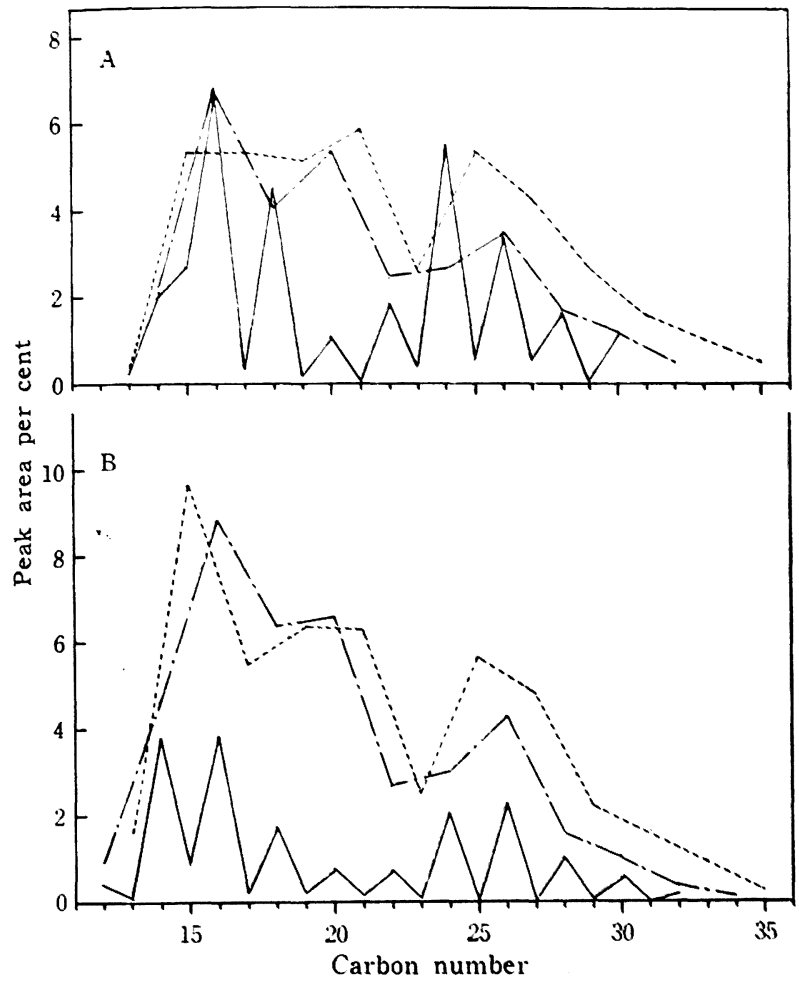

Fig. 6 Carbon chain distribution of fatty acids

$-: n-$

$--:$ iso- (Even number only)

- - : anteiso- (Odd number only)

A : Free acid

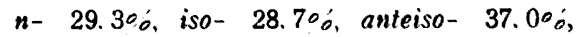
unsat. 5.00\%

B : Neutral ester $n-14.7 \%$, iso- 40.10\%, anteiso- $43.2 \%$, unsat. $1.0 \%$

は，遊雄酸，中性エステル中雨者とも炭秦数 16 と 18 の 2 種が GC-MS により確恋された。炭素数分布は炭秦数 20 付近を壋に 二つのブロックが琶められ，全体の分布は遊既酸中の方が高岑秦 数侧にシフトしていることが覞察された。

\section{3 ヒドロキシ酸}

ヒドロキシ酸は $\alpha$-ヒドロキシ酸であり，脂肪酸と同棣に分枝 ヒドロキシ酸が存在することが明らかにされておりり゙、最近では フラン環を有する新ヒドロキシ酸す検出されているき。四7には 中性エステル中のヒドロキシ酸のガスクロマトグラムを例として 示した。直鎖 $\alpha$ ーヒドロキシ酸は際準武料の保持归間か门问定を 行なったが，分枝 $\alpha$ ーヒドロキシ酸は㮩猚武料が入手でさなかっ たため，炭秦数一保持侍間の関係から佩数闻鎖の前に溶州するす のがイソー, 奇数直鎖の前に溶仙するものがアンテイソーと排定

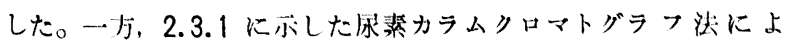

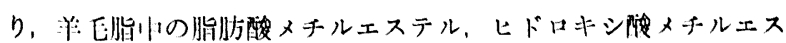

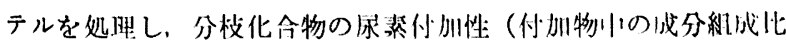

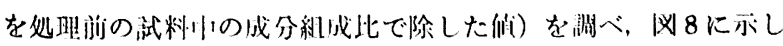
たように咸慗数に対してプロットすると、ジッザグの閔湶が得ら，

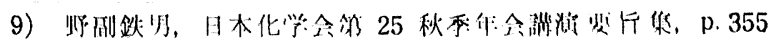
(1971).

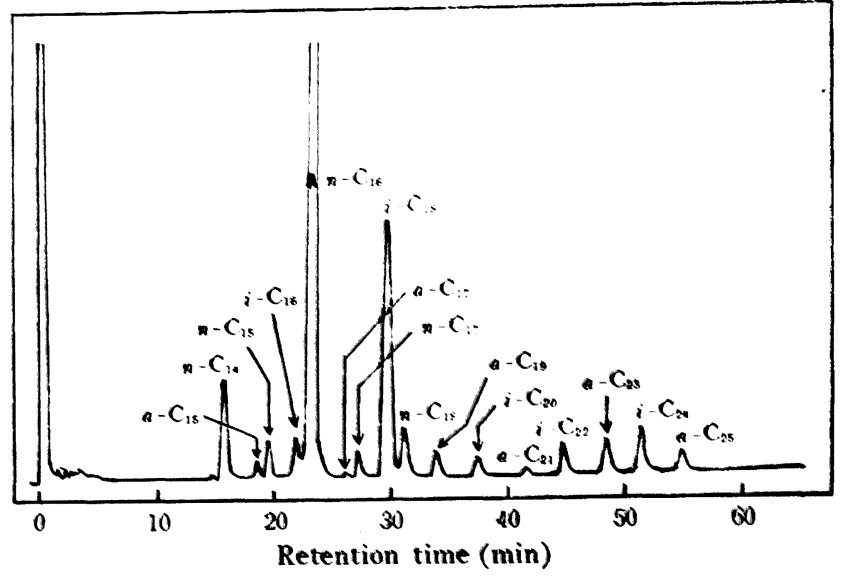

Fig. 7 Gas chromatiogram of hydroxy acid methyl ester

$n-:$ normal, $i-$ : iso-, a- : anteiso-

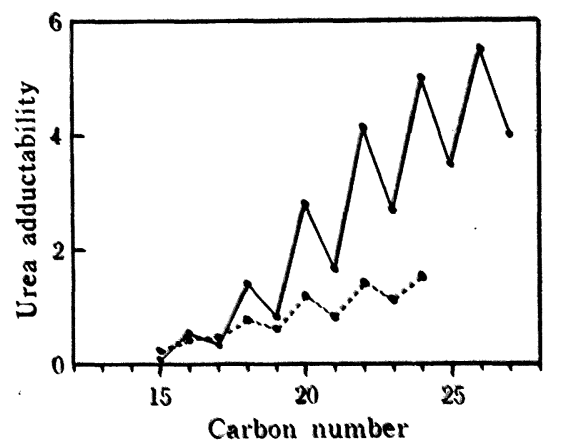

Fig. 8 Relationship between carbon number and urea adductability

- : Branched chain fatty acid methyl ester

-.. : Branched chain hydroxy acid methyl ester

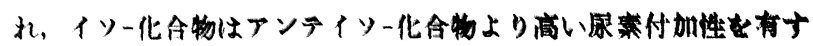

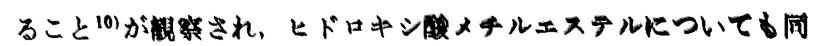
槏の佰向が翟められたため、推定棈果は正しいるのと判断した。

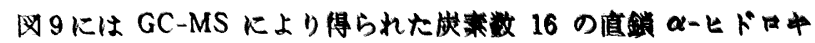
シ睃メチルエステルの質量スペクトルの概略を示した。カルボ中

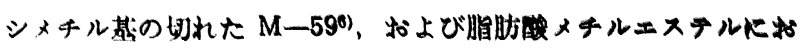
いて Mclafferty 転位によって生ずる m/e 74，87 に相当する m/e $90(74+16), 103(87+16)^{の}$ のピークが検出されたことから

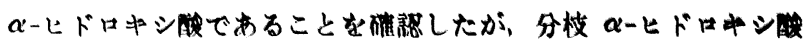

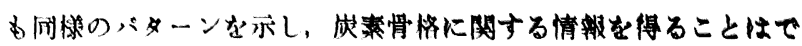

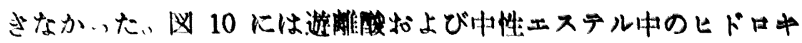

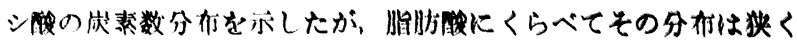

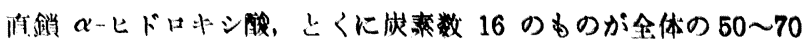

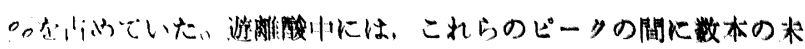

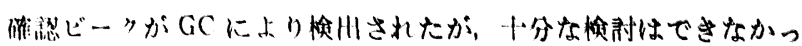
た。

\section{4 脂肪族アルコールとステロール昒の分離}

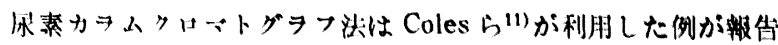

10) J. L. Iverson, R. W. Weik, J. Assoc. Offic. Agr. Chemists, 50. $1111(1967)$. 


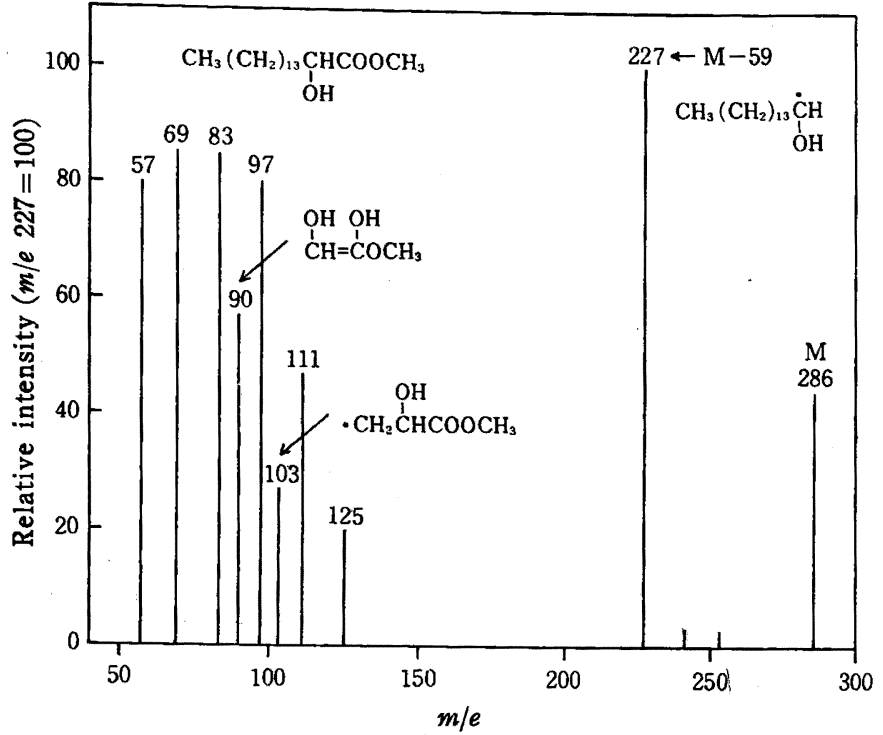

Fig. 9 Mass spectra of $n$ - $\alpha$-hydroxy $C_{18}$ acid methyl ester

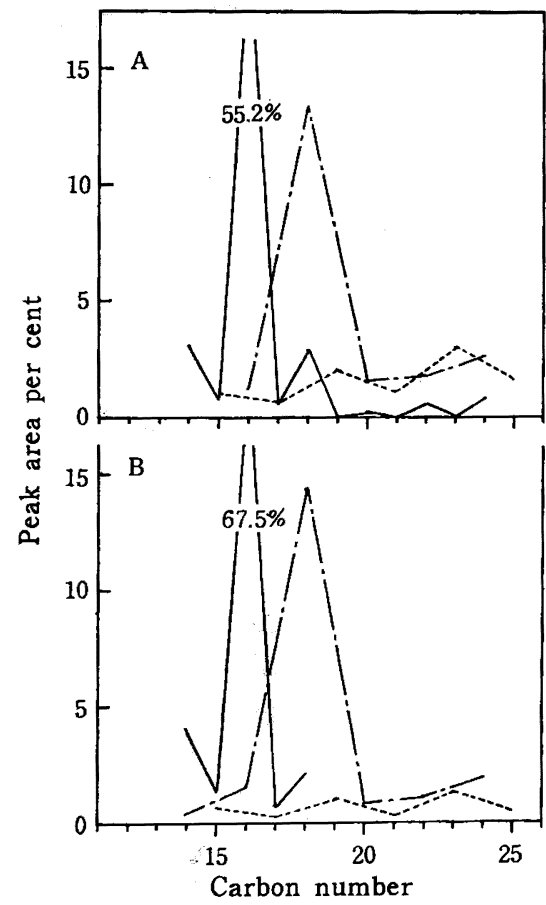

Fig. 10 Carbon chain distribution of hydroxy acids

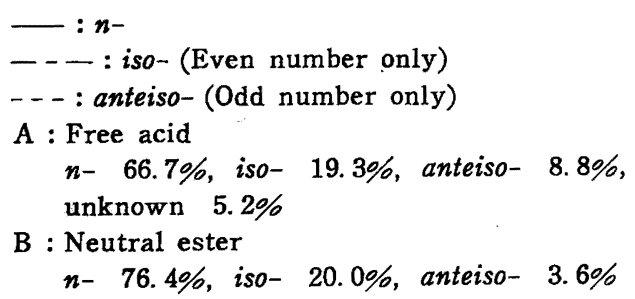

されているが, 通常の尿素付加法より抽出操作を省け, 定量的に すよい結果を示した。表 4 亿は羊毛脂のアルコール部約 $500 \mathrm{mg}$ 飞対し，尿素量を $2 ， 4 ， 6 ， 8 \mathrm{~g}$ と変えたときの尿素付加物量を 11) L. Coles, J.Chromatogr., 32, 657(1968).
Table 4 Urea adductionation of lanolin alcohol Sample : $0.4972 \mathrm{~g}$

\begin{tabular}{cc}
$\begin{array}{c}\text { Urea added } \\
(\mathrm{g})\end{array}$ & $\begin{array}{c}\text { Urea adduct } \\
(\%)\end{array}$ \\
\hline 2 & 51.6 \\
4 & 49.5 \\
6 & 50.1 \\
8 & 49.8
\end{tabular}

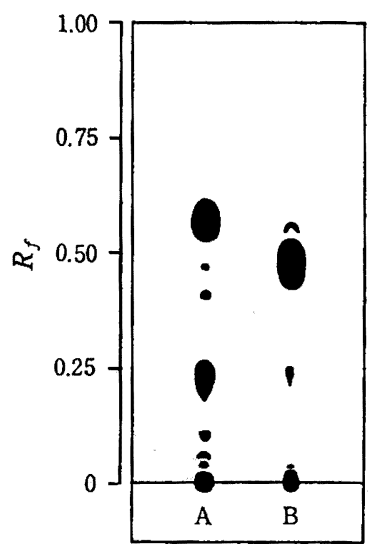

Fig. 11 Thin layer chromatogram of lanolin alcohol

A : Urea non-adduct, B : Urea adduct Adsorbent : Kiesel gel G (Merck)

Developer : Petroleum ether : Ethyl ether $(70: 30)$

Indicator : Acetic anhydride $+50 \%$ Sulfuric acid

示した。尿素量の増加に対しても，尿素付加物量は一定であり， 選択的な分離が行なわれているすのと判断した。四 11 にはTLC による検討結果を示したが，尿素付加物中にはステロール類はほ とんど検出されなかった。

\section{5 脂肪族アルコール}

脂肪族アルコール中にも，かなりの量のイソ-, アンテイソ-分 枝アルコールが存在し ${ }^{3)}$, さらに水酸基を二つるつ 1,2-ジオール が存在することが明らかにされている゙ 。羊毛脂中の脂肪族アル コールをトリメチルシリル化し，脂肪酸，ヒドロキシ酸と同様の GC 条件で分離を試みたが，良好な結果は得られず，Dexsil 300

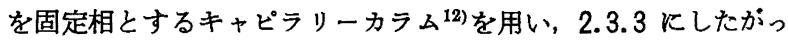
て分析を行なったところ，良好な分離を得た。四 12 には，その ガスクロマトグラムを示した。イソー, アンテイソー分枝アルコー ルの同定は2.3.4から得られたアルコールの保持時間より行なっ た。一方, アルコール部を直接 GC 分析した場合とトリメチルシ リル化し GC 分析を行なった場合の保持時間の移動率が異なるこ とから, 直鎖, イソー, アンテイソーアルコール以外のピークは水 酸基の数の多い1,2-ジオールと推定された。またこれらの保持 時間は，2.3.4によりヒドロキシ酸から得られる 1,2-ジオールの らち, 奇数炭素数のアンテイソ一骨格をすつものと一致したが, これらについては推定の域をでない。図 13 にはその炭素数分布 を示したが，約 5\% のコレステロールの混入が認められた。イ ソー, アンテイソーアルコールには脂肪酸と同様二つのブロックが 観察された。

3.6 炭化水素

炭化水素は，非常に量が少なかったため，2.3.2 の脂肪酸，七 12) M. Novotony, A. Zlatkis, J. Chromatogr., 56, 353(1971). 


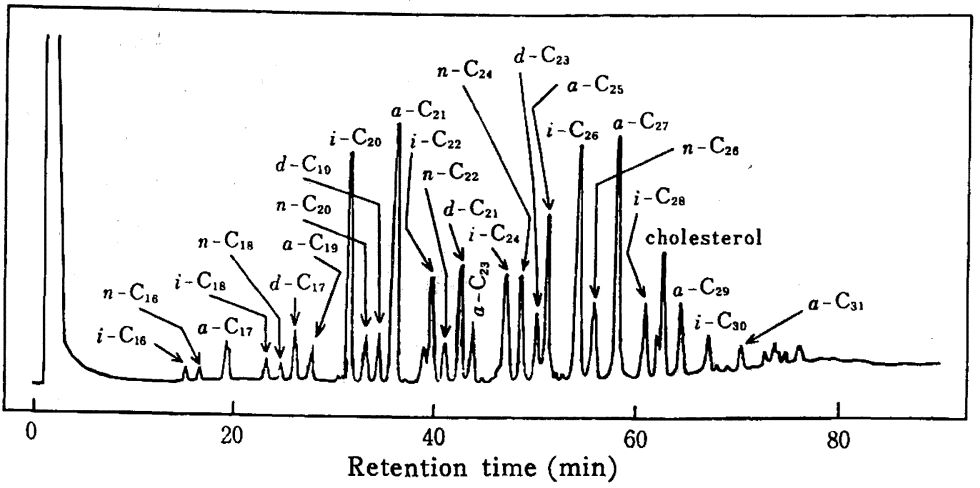

Fig. 12 Gas chromatogram of fatty alcohol TMS derivative $n$-: normal-, $i-:$ iso-, a-: anteiso-, $d-: 1,2$-diol-

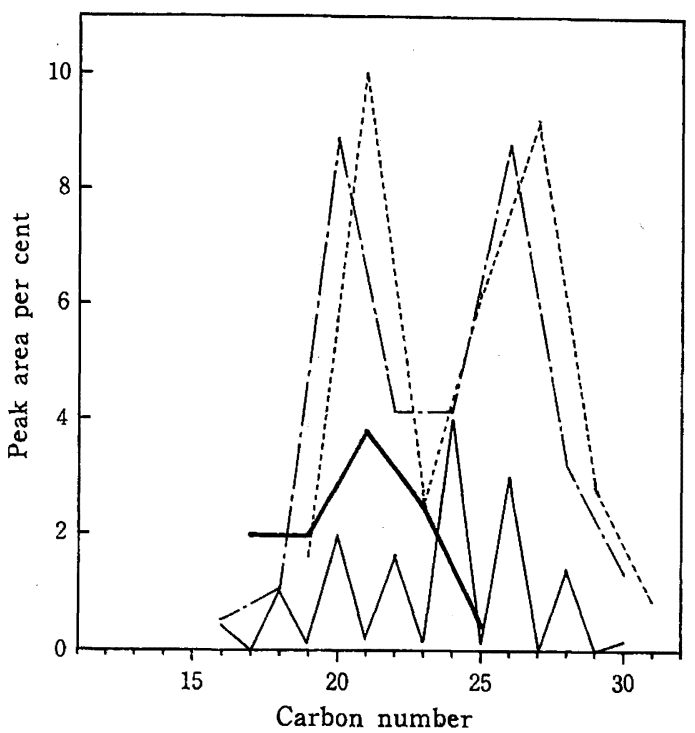

Fig. 13 Cabon chain distribution of fatty alcohol

- : n-

- - : iso- (Even number only)

- - : anteiso- (Odd number only)

- : 1,2-diol- (Odd number only)

$n-19.7 \%$, iso- $31.8 \%$, anteiso- $33.0 \%$,

1,2-diol- $10.5 \%$, sterols $5.0 \%$

ドロキシ酸の GC 条件と同一の条件のもとで, 直鎖炭化水素のみ について炭素数分布を求めた。結果を図 14 に示したが，天然口 ックスの場合と同様に奇数炭化水素が多く検出され，炭素数 31 のものが主成分であった。

\section{4 結論}

粗羊毛脂中の脂肪族化合物を系統的に分離し, 各成分中の直 鎖, イソー, アンテイソー化合物の量的な面, 扰よび拉の扮のの炭

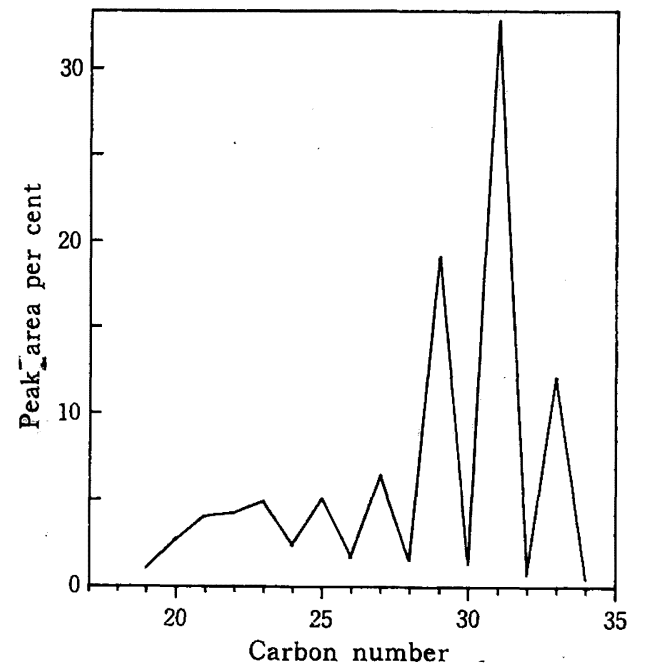

Fig. 14 Carbon chain distribution of $n$-hydrocarbon

素数分布が特徵あるパターンを有することがわかった。脂肪族ア ルコール中には奇数炭素数を有する 1,2-ジオールと推定される 成分が検出されたが，Hom ら ${ }^{13)}$ は偶数炭素数の 1,2-ジオールの 存在を報告しており，さらに検討の必要があるすのと考える。ま た分枝ヒドロキシ酸の構造確認，いくつかの未確認成分の検討な どにあわせ，もら一つの主成分であるステロール類についてす今 後さらに検討を進めていきたいと考えている。

終りに臨み，GC-MS 測定にあたり御指導，御協力いただきま した島津製作所分析センター，日立製作所応用開発課，日本電子 マス班の皆様，扣よび東京工業試験所濯田正明先生に感謝致しま す。また本報の発表を許可された株式会社資生堂専務取締役福原 信和博士，研究所長金子武夫博士飞感謝致します。

（1973 年 4 月, 日本化学会第 28 春季年会講演)

13) D. H.S. Horn, F. W. Hougen, J. Chem. Soc., 1953, 3533. 


\title{
Analysis of Fatty Compounds in Raw Lanolin ${ }^{\dagger}$
}

Tasuku Takamatsu, Tadao Ohta and Isao Matsumoto

Shiseido Laboratories ; Kamiya, Kita-ku, Tokyo 115 Japan

A systematic separation of fatty compounds in raw lanolin was carried out and the carbon chain distribution of $n-$, iso- and anteiso-components in each fatty compound was described.

First, a sample was separated into 3 groups: hydrocarbon, free acid containing acidic ester, and neutral ester, and then free acid and neutral ester were further separated into combined fatty acids, hydroxy acids and fatty alcohols. The urea column chromatography for the separation of fatty alcohols and sterols was used in addition to the systematic separation method of wax constituents which had been described in the previous paper. These isolated fatty compounds were characterized by IR, TLC, GC and partly by GC-MS.

The carbon chain distribution of fatty acids and hydroxy acids was determined by the programmed temperature GC on SE-52 as liquid phase, and the open tubular column coated with Dexsil 300 was used for fatty alcohols. It was found in this study that $n-$, iso- and anteiso-components in each fatty compound in raw lanolin showed a carbon chain distribution with characteristic patterns.

$\dagger$ Study on Components of Waxes. III.

\section{$\alpha$-オレフィンスルホン酸組成の NMR 法による分析}

\author{
（1973 年 8 月 3 日 受 理)
}

橋本茂・德若 博司・永井敏 雄*

$\boldsymbol{\alpha}$-オレフィンスルホン酸の NMR スペクトルを測定し解析した結果, アルケンスルホン酸, 1,3および 1,4-アルカンサルトンを含んでいたが，アルカリ条件下で加水分解した $\alpha$-オレフィンスルホン

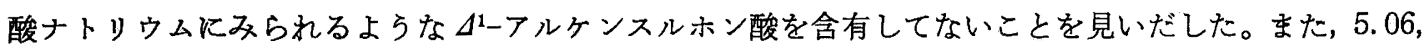
$3.43 \mathrm{ppm}$ 飞州属できないピークがあったが，これらのピークを带属するためにいろいろ検討した結果，

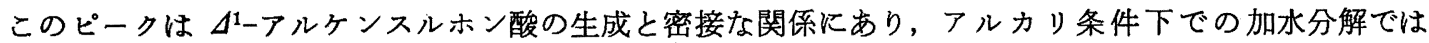
பاーアルケンスルホン酸を与えることがわかった。この事実と化学シフト位置などから考光，長鎖 $\alpha$-オ レフィンスルホン酸でいまだ見いだされていなかった 1,2 -アルカンジーサルトンの>CH-O, $-\mathrm{CH}_{2}-$ $\mathrm{SO}_{2}$-プロトンによるピークと帰属することができた。この知見はスルホン化における初期生成物，ス ルホン化機構の研究に役立つと考えられる。

NMR スペクトルの解析結果に基づき， $\alpha$-オレフィンスルホン酸中のアルケンスルホン酸, アルカン サルトン拉よび 1,2-アルカンジーサルトンを簡単に定量分析することができ, この方法は, 炭素鎖長分 布のある AOS 酸にも適用できる長所を有する。

\section{1 粕言}

長鎖 $\alpha$-オレフィンを無水硫酸でスルホン化すると，アルカン サルトン, アルケンスルホン酸などからなる複雑な組成をすつ混 合物を生成することが知られている1) 。市。れらのスルホン化物

* ライオン油脂株式会社中央研究所, 132 東京都江戸川区 平井

1) F. G. Bordwell, C. S. Rondestvedt, J. Amer. Chem. Soc., 70, 2429(1948).
をアルカリ性で加水分解して得られる $\alpha$-オレフィンスルホン酸 ナトリウム（以下 AOS と略記する）は，良好な生分解性をすつ 界面活性剤でありあ，洗剂原料として広く用いられている

2) F. Püsche1, C. Kaiser, Chem. Ber., 98, 735(1965).

3) F. G. Bordwell, F. B. Colton, M. Knell, J. Amer. Chem. Soc., 76, 3950(1954).

4) F. G. Bordwell, R. D. Chapman, C. E. Osborne, ibid., 81, 2002(1959).

5) 大場健吉, 森昭, 富山新一, 油化学, 17, 517(1968). 